\title{
Endoscopic Brow Lift
}

\author{
Ji Yun Choi \\ Department of Otorhinolaryngology-Head and Neck Surgery, School of Medicine, Chosun University, Gwangju, Korea
}

\section{내시경적 이마거상술}

\author{
최 지 윤 \\ 조선대학교 의학전문대학원 이비인후과학교실
}

\author{
Received September 16, 2016 \\ Revised November 22, 2016 \\ Accepted November 25, 2016 \\ Address for correspondence \\ Ji Yun Choi, MD, PhD \\ Department of Otorhinolaryngology- \\ Head and Neck Surgery, \\ School of Medicine, \\ Chosun University, \\ 365 Pilmun-daero, Dong-gu, \\ Gwangju 61453, Korea \\ Tel +82-62-220-3200 \\ Fax +82-62-225 2702 \\ E-mail happyent@naver.com
}

Eyebrows play a significant role in an individual's expression of emotions and nonverbal communications. Nonendoscopic approaches to brow lifting include the coronal, pretrichial, direct, midforehead, and transblepharoplasty approaches. Endoscopic brow lift has become widely accepted as a procedure for restoring a youthful brow, hardly noticeable incisions of the scalp are needed for this subperiosteal dissection and final repositioning of the brow. The choice of incision and approach is based on the patient's forehead height and hairline position, and the patient's desired effect and surgeon's comfort and experience with a given procedure. Endoscopic brow lift is a predictable procedure for rejuvenation of the upper third of the face with minimal complications and obtains satisfactory aesthetic results.

Korean J Otorhinolaryngol-Head Neck Surg 2017;60(1):1-6

Key Words Brow lift $\cdot$ Endoscopic $\cdot$ Forehead $\cdot$ Rejuvenation.

\section{서 론}

얼굴의 노화는 피부에서 지방층, 안면골까지 전층에 걸쳐 발생한다. 안면거상술은 나이가 들어감에 따라 늘어진 연부 조직을 당겨 올려 젊은 모습으로 되돌려주는 술기로 얼굴피 부의 늘어짐과 주름에 대한 교정에 목적이 있다. 눈썹과 이 마는 눈주변 중심부위로 얼굴표정과 인상을 결정짓는 데 중 요한 역할을 하는데 눈썹의 정상 위치는 안와위경계를 기준 으로 남자는 약간 아래에 일자형으로 위치하고, 여자는 외측 으로 가면서 약간 위로 올라가는 아치형을 이룬다. ${ }^{1)}$ 눈썹은 피 하조직층과 눈썹피부가 골막과 단단히 연결되지 않아서 쉽 게 처지며 다른 부위에 비해 일찍 노화가 시작된다. 이마거상 술의 치료목적은 처진 눈썹을 올리고 눈썹모양을 수정하고 비대칭 눈썹을 교정하고 이마의 주름을 개선하는 것에 있다. 노화가 진행됨에 따라 눈과 눈썹의 변화도 오게 되는데 눈주 변의 지방이 줄어들면서 눈이 더 들어가 보이고 상안검의 피 부는 늘어지고 처지며, 눈썹, 특히 전두근의 영향을 덜 받는 바깥쪽이 처지게 된다. 이러한 변화로 인해 시야가 가려지기 때
문에 무의식적으로 눈썹을 올리게 되는 reflex brow raising 현상으로 이마의 주름이 깊어지게 된다. ${ }^{1)}$ Gunter와 Antrobus ${ }^{1)}$ 는 눈썹과 팔자주름(nasojugal folds)이 타원형 모양을 만들 며 동공이 그 타원형의 장경에 위치할 때 아름다운 눈이라고 기술하였고, 속눈썹에서 쌍꺼풀까지의 높이가 속눈썹에서 눈 썹 하연까지 길이의 $1 / 3$ 정도일 때 아름답다고 하였다.

\section{해 부}

전두근은 모상건막(galea)에서 기시하여 전두부 피부에 부착하고, 이마의 유일한 거상근으로서 역할을 하며, 안면신 경의 전두분지의 지배를 받는다. 이에 반해 내림근의 역할을 하는 근육은 여러 가지인데 추미근(corrugator supercilii), 안 륜근(orbicularis oculi), 비근근(procerus muscle)이 좌우에 쌍으로 존재하며, 추미근은 미간의 세로 주름을 만들고, 비 근근은 가로 주름을 만든다(Fig. 1). ${ }^{2,3)}$

이상적인 눈썹의 위치는 남녀 간에 약간의 차이가 있는데 남자는 두껍고 수평으로 놓여 있다. 안와상연에 걸쳐 있거나 

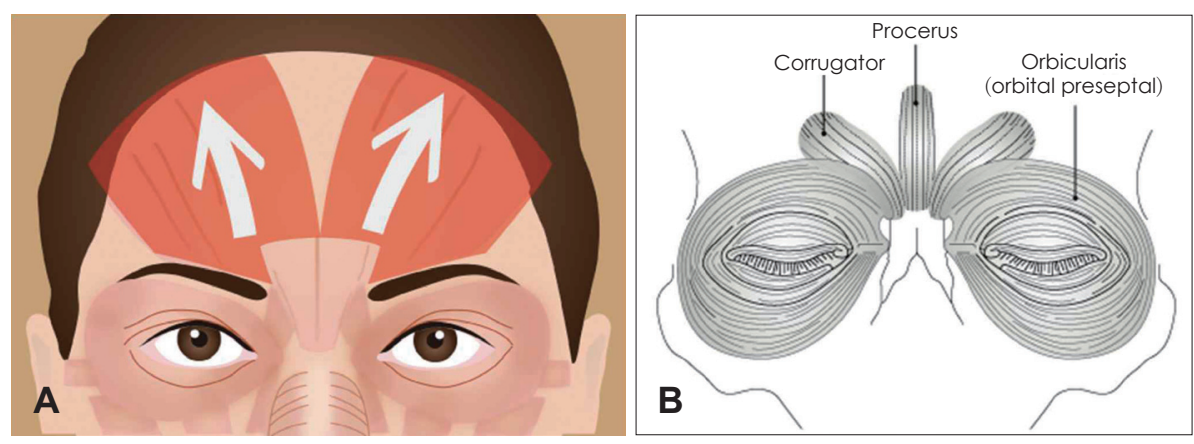

Fig. 1. This figuers show forehead elevator and depressor muscles. The frontalis muscles are forehead elevators (A). The procerus, corrugator, orbicularis oculi muslces are depressors (B).
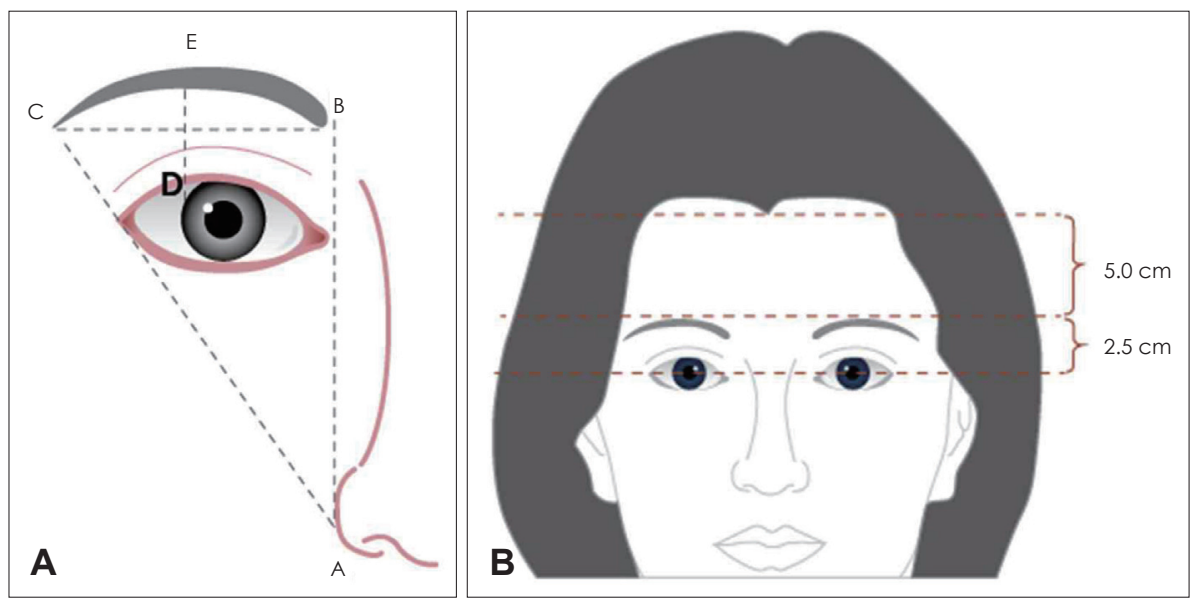

Fig. 2. Ideal brow position in a woman. The lateral brow lies at or above the medial brow (BC). Themedial brow begins along a vertical line drawn from the nasal ala (AB). The brow peaks at the laterallimbus of the iris (DE). The lateral brow extends to a line drawn through the lateral canthus to the ala (AC) (A). The distance from midpupil to the top of the brow should be at least 2.5 $\mathrm{cm}$, the forehead height averages 5 $\mathrm{cm}$ in female and $6 \mathrm{~cm}$ in male (B).

이보다 낮게 위치한다. 여자에서는 안와상연보다 높게 위치 하며 내측이 두껍고 외측이 가는 아치형태를 이룬다. 눈썹의 내측 경계와 내안각과 같은 수직선상에 위치하며 눈썹의 가 장 높은 부분이 눈썹의 바깥쪽 $2 / 3$ 또는 동공의 외측경계선 상에 위치한다. 눈썹의 외측이 내측에 비해 높이 위치한다. 눈썹의 외측경계는 외안각과 비저(alar base)를 연결하는 선 상에 위치한다(Fig. 2). ${ }^{1,4)}$

\section{수술 전 평가}

환자를 진찰할 때 주의해야 할 것은 전두근의 작용에 의 해 눈썹이 지속적으로 거상되어 있는 환자들이 많다는 것이 다. 전두근의 영향을 없애기 위해 환자에게 눈을 20초간 감 게 하고 이마를 이완시키고, 천천히 눈을 뜨게 하여 전두근의 영향이 없는 상태에서 눈썹과 눈꺼풀의 처짐이 어느 정도인 지를 파악해야 한다. 이 검사를 통해 많은 환자들이 reflex brow lifting을 하고 있다는 사실을 알 수 있다. 이를 간과하게 되면 눈썹 처짐에 의한 것을 단순히 상안검처짐(upper eyelid dermatochalasis)으로 생각하고 이마/눈썹거상술(forehead/ browlift) 없이 상안검성형술만을 시행하는 경우가 생긴다. 이 럴 경우 눈과 눈썹이 더욱 가까워져서 눈의 모양이 더욱 안 좋 아지고 다시 교정하기가 매우 어려우므로 주의하여야 한다.

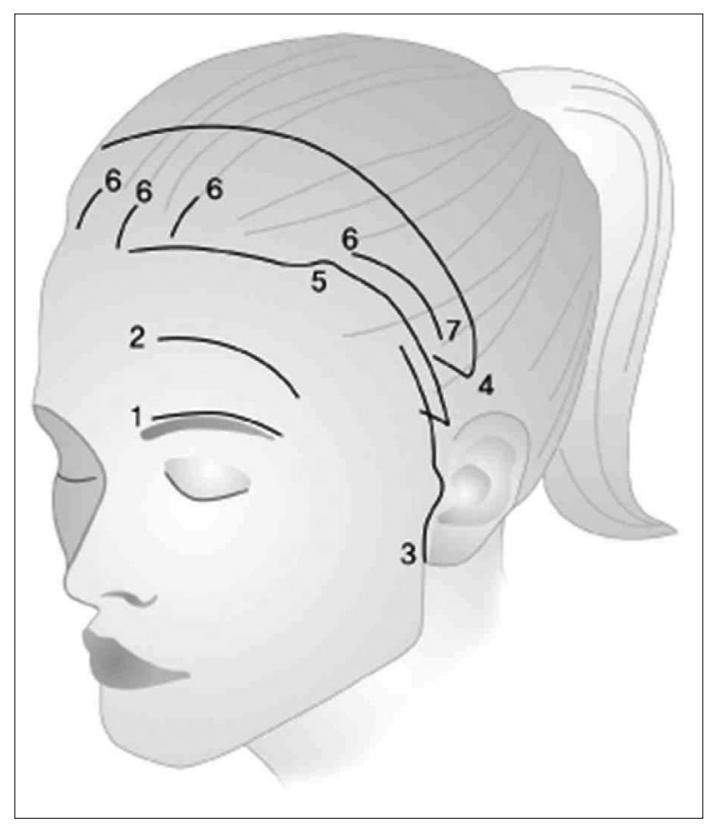

Fig. 3. Various browplasty techniques. 1. Direct brow lift, 2. Midforehead, 3. Temporal extension of rhythidectomy incision, 4. Coronal incision, 5. Pretrichial incision, 6. Endoscopic forehead, 7. Temporal endoscopic.

쌍꺼풀 선과 눈썹과의 거리가 $1.5 \mathrm{~cm}$ 정도는 유지하도록 해 야 한다. ${ }^{5}$

상안면에 대한 다양한 수술 방법이 소개되어 왔으며 접근 
방법에 따른 눈썹올림술의 종류는 관상절개눈썹올림술 (coronal brow lift), 모발앞눈썹올림술(pretrichial brow lift), 이마중앙눈썹올림술(midforehead brow lift), 측두눈썹올림 술(temporal brow lift), 직접눈썹올림술(direct brow lift), 눈 꺼풀경유눈썹올림술(transblepharoplasty brow lift), 내시경 눈썹올림술(endoscopic brow lift) 등이 있다(Fig. 3).

\section{수술 방법}

\section{내시경을 이용한 안면거상술}

내시경을 이용한 이마거상술의 장점은 절개를 최소화하고 두피의 지속적인 감각저하 및 탈모를 예방할 수 있다는 것이 다. 평균적인 이마의 높이를 가지면서 경도나 중등도의 눈썹 하수에 적절한 술식이다. 눈썹하수가 너무 심하거나 피부가 너무 두꺼운 경우, 이마가 튀어나온 경우, 대머리나 두발선이 높은 경우에는 수술에 제한이 따른다. 두발선이 높은 경우, 내시경적 이마거상술과 함께 모발선앞피부절제술을 동시에 시행하면 좋은 효과를 보인다. 보통 수술 2주 전에 보튤리즘 톡신(botulinum toxin) $\mathrm{A}$ 를 눈썹 내측부위(central brow)와 미간내림근(glabella depressor muscle)에 주사를 시행하여 수술 후 올려진 눈썹이 잘 유지되도록 돕는다(Fig. 4). 전두 부근육에는 주사해서는 안된다. 다른 방법으로는 수술 중 추 미근과 비근근을 부분적으로 제거하는 방법도 있다. 미간의 근육을 과도하게 제거를 시행하면 내측 눈썹(medial brow) 이 비정상적으로 상승하거나 넓어질 수 있으므로 주의를 요 한다. 수술 전 앉은 자세에서 눈썹의 위치를 평가하고 절개 부위를 표시한다. 눈썹을 상승시킬 양과 벡터를 정하여 이마 와 측두부에 표시를 시행한다. 대부분 여성의 경우에는 수직 방향으로 남자는 상외측으로 거상을 시행한다. 다음으로 안와 상절흔(supraorbital notch), 상활차신경(supratrochlear nerve),

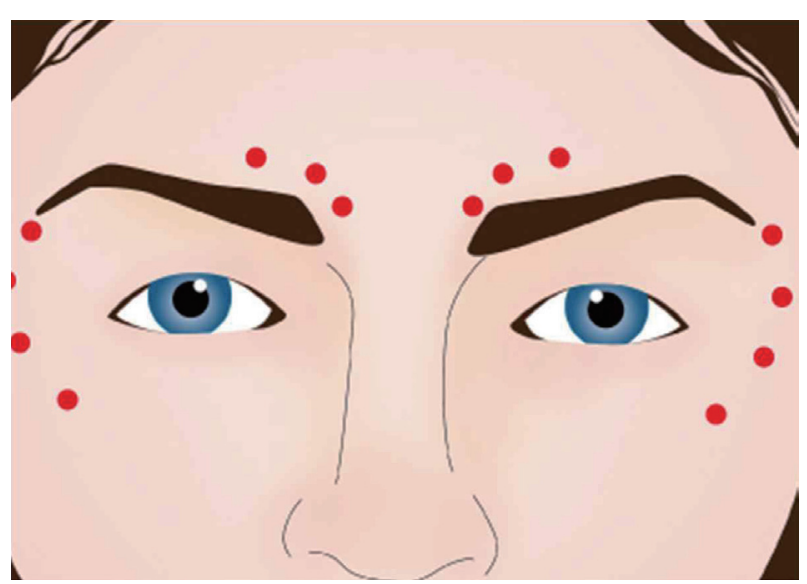

Fig. 4. Sites for preoperative botulinum toxin injection. glabellar infrowning lines, 안면신경의 전두가지(frontal branch)의 주행경로 등 주요 해부학적 이정표(landmark)들 을 표시한다. 마취는 일반적으로 전신마취 또는 정맥마취를 하며 추가로 수술부위에 에피네프린이 포함된 리도카인을 국소 침윤마취를 시행한다. 약 15 20분 정도 기다려 혈관이 수축된 후 15 번 메스를 이용하여 골막하에 이르기까지 절개 를 시행한다. 절개선은 모발선의 직후방에 이마의 중앙부와 양측면(외측 눈썹부위 또는 관자선의 $1 \mathrm{~cm}$ 내측)에 $1.5 \sim 2.0$ $\mathrm{cm}$ 크기로 세 개의 절개선을 넣는다. 절개는 골막하까지 전 층절개를 시행하며 절개선 주변의 골막하 박리를 시행한다. 나중에 고정할 때 골막이 잘 유지되어야 하므로 골막이 손 상되지 않도록 조심해서 박리한다. 내시경을 사용하지 않고 길고 폭이 넓은 골막박리기를 이용하여 전두부 박리를 안와 상부 $2 \mathrm{~cm}$ 까지 시행한다. 외측으로는 관자선(temporal line)까 지, 후방으로는 2 3 cm 정도 두피를 박리한다. 다음으로 sheath 를 쓰운 30도 내시경으로 직접 박리 부위를 보면서 상안와신 경혈관다발(supraorbital neurovascular bundles), 활자상신 경혈관다발 주변을 박리한다. 이마 부위의 절개선 세 개 중 한 쪽은 내시경을 넣고 다른 한쪽에는 수술기구를 넣는 방식으 로 박리를 진행하게 된다. 이곳은 추미근, 비근근의 근섬유 사이로 신경과 혈관이 있으므로 근섬유의 방향과 평행하게 작 고 긴 골막박리기로 박리하고, 필요하면 근육들을 절제한다. 주의할 점은 너무 많이 제거하면 미간이 넓어지거나, 미간에 함몰이 생길 수 있으니 주의한다. 눈썹 내측의 박리가 끝나면, 안와를 둘러싼 모서리활(arcus marginalis)을 외측부터 시작 하여 내측으로 신경과 혈관이 손상되지 않도록 주의하면서 박리를 시행한다. 안와의 외측에서 골막에 절개를 시행하고 내측의 지방을 노출시켜 추가적인 박리를 시행한다. 이곳을 충분히 박리하여야 거상시킬 수 있는 피판의 가동성을 얻을 수 있다.

다음으로 측두부의 절개로 옮겨 박리를 진행한다. 측두부 절개는 $1.5 \sim 2 \mathrm{~cm}$ 정도의 크기로 모발선의 $2 \mathrm{~cm}$ 후방에 측두 근이 있는 두피 내에 넣으며 절개는 피부와 피하층, 측두두정 근막(temporoparietal fascia)까지 진행하고 박리되는 층은 측두두정근막(temporoparietal fascia) 아래, 심층측두근막 (deep temporal fascia) 상부가 된다. 절개를 넣을 때 모근이 다치지 않도록 모근과 평행하도록 절개선을 넣는다. 이마/눈 썹거상술만 하는 경우 박리범위는 아래로 외안각위치(lateral canthus level)가 되고, 전방으로 관자선까지가 된다. 저자는 측 두부 절개를 3 4 $\mathrm{cm}$ 정도로 길게 연장하고 $1 \sim 1.5 \mathrm{~cm}$ 정도의 두께로 피부를 절제한 후 $2 \mathrm{~cm}$ 피하박리를 시행하여 당겨서 봉합을 시행한다. 이렇게 하면 외측눈가주름을 제거하고 외 측 눈썹을 거상하는 데 추가적인 도움을 준다. 전술한 바와 

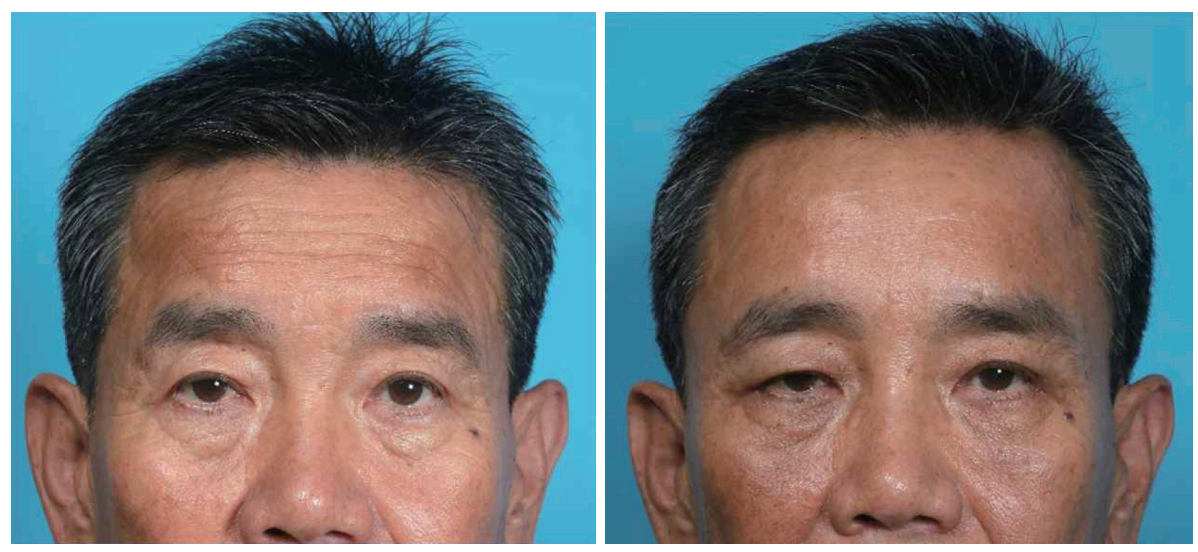

Fig. 5. 63-years-old male shows before and 3 months after endoscopic browlift.

같이 이곳을 박리하는 중에 sentinel vein을 만나게 되는데 안면신경 전두분지가 그 위에 있다는 표시이므로 그 주변에 소작을 할 때 매우 주의하여야 한다. 양측에 측두부 박리가 끝나면 골막박리기를 관자선 외측에서 내측으로 통과시켜 박리하고 중앙 박리부와 연결하여 하나의 큰 피판을 만든다. 두개의 포켓이 연결되면 내시경용 골막박리기의 모서리를 이 용하여 위에서 아래방향으로 측두부유합부(conjoined tendon, temporal attachment)를 박리한다. 양측 측두부는 3-0 polydioxanone(PDS)과 같은 두꺼운 흡수사를 이용하여 측 두두정피판을 아래쪽 심층측두근막에 단단히 고정한 후 피 부를 봉합한다. 중앙부는 두개골의 양측에 bone bridge system을 이용하여 뼈터널(bone tunnel)을 만들어 그곳으로 2-0 $\mathrm{PDS}$ 를 통과시켜 두개골막을 포함한 전층피부에 고정하던가 아니면 마이크로스크류(microscrew)를 박아서 이곳에 고정 하거나 엔도타인(endontine)으로 고정할 수도 있다. 마지막으 로 절개부를 피부스테플러를 이용하여 봉합한다(Fig. 5). ${ }^{6}$

\section{합 병 증}

\section{신경손상}

운동신경인 얼굴신경의 측두분지와 감각신경인 위 도르래 신경과 위 안와신경의 손상이 발생할 수 있다. 이마의 감각이 상은 중앙 또는 측두피판의 절개가 위 안와신경의 주행쪽으 로 확장될 때 일어날 수 있으며, 또한 신경주행부위에 소작기 를 과도하게 사용하면 신경손상을 일으킬 수 있다.)

\section{상처, 반흔}

눈썹과 이마는 눈에 잘 띄는 부위이다. 눈썹올림술에 의해 흥터가 생길 수 있다. 흥터는 박피술이나 필러를 이용해 가려 질 수 있다. 흉터를 가리기 위해 문신이나 머리카락이식술이 시행되기도 한다. 모발선앞 절개술 또는 내시경적 이마올림 술이 흥터를 최소화 할 수 있다. ${ }^{6}$

\section{혈 종}

지혈을 세심하게 하지 않으면 측두 또는 관상피판 아래로 큰 혈종이 생길 수 있고, 이는 피판의 괴사를 초래할 수 있다. 두피 혈종이 생기고 점점 커지면 봉합부위를 열어 출혈되는 혈관을 찾아 소작해야 한다.

\section{탈모증}

탈모증은 봉합이 적절하지 않은 경우, 절개부위에 긴장이 심하게 걸린 경우, 모낭부위에 전기소작기를 많이 사용한 경우 에 발생할 수 있다. 박리가 너무 표층에 이루어질 경우에도 머 리카락 모낭의 손상이 일어날 수 있다.

\section{모발선앞 접근법과 관상절개술(Pretrichial and coronal approaches)}

관상절개술은 전통적으로 두발선이 낮은 환자에게 이상적 인 술식인 반면 모발선앞 눈썹올림술은 모발선이 위로 많이 물러나 있고 이마의 피부주름이 깊지 않고 앞쪽 모발의 숱이 많은 경우에 좋은 적응증이 된다. 일반적으로 이마가 넓은 것 보다 좁은 것이 더 젊어 보이는 인상을 주므로 모발선앞 절개 술이 유용하다. 모발선을 따라 절개하기 때문에 수술 후 관 상절개 올림술 시 나타나는 모발선의 후퇴나 이마가 넓어지는 변화가 없고 측두부의 모발선을 유지할 수 있다는 장점이 있 다. 관상절개 올림술을 받았던 환자에서 재수술이 필요할 때 시행할 수 있다. ${ }^{7)}$

관상절개술은 두발선의 상부에 절개를 시행하는 반면 모발 선앞 절개는 앞이마 두발선을 따라 양쪽 관자놀이까지 진행 된다. 두피절개는 머리카락의 한 줄 혹은 두 줄을 포함하는 두피의 표피층을 제거하고, 두발선의 약 $2 \mathrm{~mm}$ 후방에서 비 스듬하게 절개하여 표피피판을 만든다. 이마 중앙부위를 박 리할 때 상안와신경 절단으로 수술 후 두피에 마비가 올 수 있 다. 최근에는 모발선앞 접근법의 단점을 보완하여 피하박리 를 통해 피부를 제거하고 내시경눈썹올림술을 동시에 시행 
하여 신경손상을 줄이면서 이마의 높이를 낮추는 수술 방법 이 소개되었다. ${ }^{8,9)}$

관상절개술은 모발선이 낮고 주름이 깊으며 눈썹이 심하 게 처진 경우에 좋은 적응즉이 된다. 수술결과가 오래 지속되 는 장점을 보이지만 흥터, 감각저하, 모발선의 후퇴, 탈모는 커 다란 단점이다. 두발선의 5 7 cm 상부에 양측 측두부를 연결 하는 긴 절개를 가한 후 모상건막하 층을 따라 안와상부까 지 박리를 시행한다. 직시하에 신경, 혈관다발(상안와신경, 활 차상신경)을 확인하고 손상을 최소화한다. 안와상부를 따라 모서리활, 골막, 병합건(conjoined tendon)을 분리하여 눈썹 을 충분히 이동시킨다. 추미근과 비근근 근육을 확인하고 절 제한다. 추가로 전두근에 절개를 가하여 이마주름을 부드럽 게 만든다. 두피를 다시 덮고 후·상방으로 들어올린 후 여분 의 피부를 제거하고 층층이 봉합을 시행한다.

\section{직접눈썹올림술(Direct brow lift approach)}

직접눈썹올림술은 눈썹의 직상방과 상부에 2 개의 절개선 을 가한 후 피하박리를 시행하여 봉합하는 술식이다. 부분마 취나 수면마취로 수술이 가능하며 술 후 부종과 출혈이 적은 장점이 있다. 반면에 술 후 눈썹의 소실과 흥터가 발생할 수 있 다는 단점이 있다. 따라서 나이가 많거나 기저질환이 있는 환 자에서 좋은 적응이 된다.

아래절개선은 눈썹 바로 위를 따라 표시하며, 위절개선은 다음과 같은 방법으로 그린다. 환자를 앉힌 상태에서 눈썹위 이마를 위로 당겨 눈썹을 원하는 위치까지 올린 다음, 올라 간 아래절개선에 표시펜을 위치시킨다. 그리고 위로 당긴 이 마를 놓아서 눈썹이 원래 위치로 내려갔을 때 표시펜이 놓이 는 이마 피부에 점을 찍어 표시한다. 몇 군데 반복하여 표시 하고 표시된 점들을 연결하여 위절개선을 그린다. 안쪽에서 위·아래경계선은 꼬리가 내려가는 모양으로 만나고, 바깥쪽 에서는 꼬리가 30도가량 올라가도록 S 모양으로 도안하기도 하는데, 이는 수술 후 흉터가 덜 드러나도록 하는 효과가 있 다. 눈썹꼬리부위에서는 가쪽으로 $1 \mathrm{~cm}$ 이상 벗어나지 않도 록 하는데 이는 얼굴신경 이마분지의 손상을 예방하기 위함 이다. ${ }^{10)}$

\section{중이마접근법(Midforehead approach)}

중이마접근법은 전신마취 또는 수면마취하에 시행이 가능 하다. 주름이 깊거나 두발선이 높거나 눈썹의 위치가 비대칭
이거나 일측안면마비가 있는 경우에 좋은 적응이 된다. 절개 선은 깊은 주름위에 놓이게 되며 대부분 양측 절개선이 다른 높이에 위치하게 된다. 술식이 간단하며 피하박리를 시행하 여야 두피의 감각이상을 예방할 수 있다.

\section{결 론}

지금까지 상안면부의 노화를 개선하기 위한 다양한 수술 방법이 보고되어 왔다. 내시경적 이마거상술은 기존의 술식 에 비해 흥터 및 합병증이 적고 회복기간이 빠르며 효과적인 술식인 반면 장비가 필요하고 수술에 익숙해지는 데 시간과 경험을 요한다. 내시경적 이마거상술은 모발선이 낮고 이마 의 빼가 편평하고 이마의 피부가 많이 늘어나지 않은 사람이 좋은 결과를 보인다. 출혈을 줄이고 회복기간을 짧게 하기 위 해서는 수술 전 에피네프린이 포함된 리도케인을 충분히 주 입하고 지혈을 철저히 해야 하며 술 후 압박드레싱과 혈종의 제거에 주의를 기울여야 한다. 눈썹이나 이마를 거상하는 수 술은 여러 가지 종류가 있으므로 장·단점을 파악하고 충분 한 상담을 통해 환자에게 적절한 술식을 사용하는 것이 좋 을 것으로 사료된다.

\section{REFERENCES}

1) Gunter JP, Antrobus SD. Aesthetic analysis of the eyebrows. Plast Reconstr Surg 1997;99(7):1808-16.

2) Flowers RS, Caputy GG, Flowers SS. The biomechanics of brow and frontalis function and its effect on blepharoplasty. Clin Plast Surg 1993;20(2):255-68.

3) Pitanguy I. Section of the frontalis-procerus-corrugator aponeurosis in the correction of frontal and glabellar wrinkles. Ann Plast Surg 1979;2(5):422-7.

4) Westmore MG. Facial cosmetics in conjunction with surgery. Course presented at the Aesthetic Plastic Surgery Society Meeting. Vancouver, British Columbia, May of 1975.

5) Dailey RA, Saulny SM. Current treatments for brow ptosis. Curr Opin Ophthalmol 2003;14(5):260-6.

6) Javidnia H, Sykes J. Endoscopic brow lifts: have they replaced coronal lifts? Facial Plast Surg Clin North Am 2013;21(2):191-9.

7) Cilento BW, Johnson CM Jr. The case for open forehead rejuvenation: a review of 1004 procedures. Arch Facial Plast Surg 2009;11(1):13-7.

8) Perkins SW, Batniji RK. Trichophytic endoscopic forehead-lifting in high hairline patients. Facial Plast Surg Clin North Am 2006;14(3): 185-93.

9) Holcomb JD, McCollough EG. Trichophytic incisional approaches to upper facial rejuvenation. Arch Facial Plast Surg 2001;3(1):48-53.

10) Booth AJ, Murray A, Tyers AG. The direct brow lift: efficacy, complications, and patient satisfaction. Br J Ophthalmol 2004;88(5): 688-91. 
Korean J Otorhinolaryngol-Head Neck Surg I 2017;60(1):1-6

\section{정답 및 해설}

답 (3)

해 설 치성감염에 의한 경우가 가장 많고, 면역기능이 정상인 경우에도 발생할 수 있으며 일차적으로 수술적 치료를 한다. 전 신적으로 패혈증과 종격동염등의 합병증 등이 발생할 수 있다. 